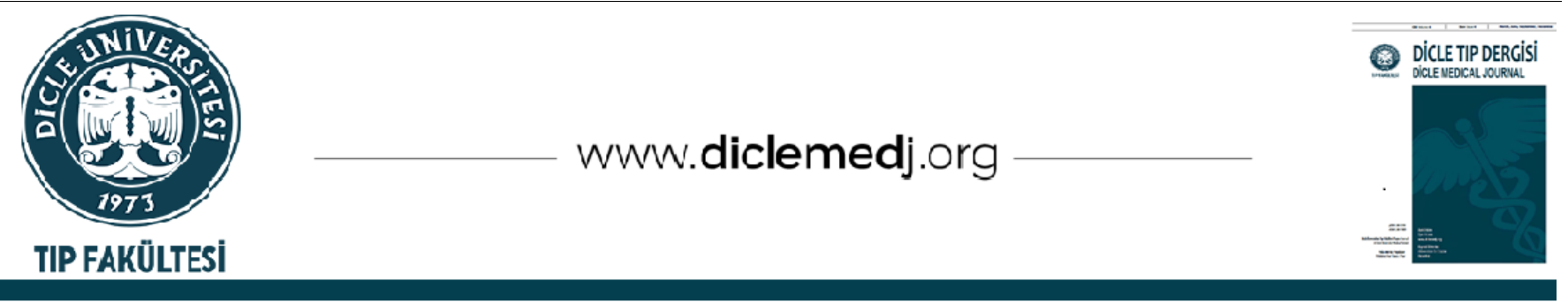

\title{
Parkinson Hastalığında Depresif Belirtiler ve Fiziksel Aktivite Seviyesi Arasındaki İlişkinin İncelenmesi
}

\author{
Selin Koç ${ }^{1}$ 1, Engin Ramazanoğlu i 1 , Burcu Talu ${ }^{1}{ }_{1}$ \\ 1 İnönü Üniversitesi, Sağlık Bilimleri Enstitüsü, Fizyoterapi ve Rehabilitasyon Bölümü, Malatya, Türkiye
}

Geliş: 23.06.2021; Revizyon: 17.11.2021; Kabul Tarihi: 22.11.2021

Öz

Amaç: Bu çalışmanın amacı, Parkinson hastalığında depresif belirtiler ile fiziksel aktivite seviyesi arasındaki ilişkinin incelenmesidir.

Yöntemler: Bu prospektif çalışmaya; Mart 2018- Eylül 2018 tarihleri arasında yaşları 58-89 arasında değişen 25 kadın $(\% 36,2), 44$ erkek $(\% 63,8)$ olmak üzere toplam 69 hasta dahil edildi. Parkinson hastalarında depresif belirtilerin şiddetini belirlemek için Hamilton Depresyon Değerlendirme Ölçeği, fiziksel aktivite seviyesini belirlemek için Uluslararası Fiziksel Aktivite Ölçeği (Kısa Form) kullanıldı.

Bulgular: Tüm hastalarda ve erkeklerde; uluslararası fiziksel aktivite ölçeği ve hamilton depresyon değerlendirme ölçeği arasında negatif yönde orta şiddette anlamlı korelasyon görülürken, kadınlarda istatiksel olarak anlamlı korelasyon bulunmamaktadır. Tüm hastalarda, kadınlarda ve erkeklerde yaş ile uluslararası fiziksel aktivite ölçeği arasında negatif yönde orta şiddette anlamlı korelasyon görüldü. Tüm hastalarda ve kadınlarda hamilton depresyon değerlendirme ölçeği ile yaş arasında; pozitif yönde orta şiddette anlamlı korelasyon bulunurken, erkeklerde pozitif yönde yüksek şiddette anlamlı korelasyon bulundu. Tüm hastalarda ve kadınlarda vücut kütle indeksi ve hamilton depresyon değerlendirme ölçeği arasında; pozitif yönde orta şiddette anlamlı korelasyon görülürken, erkeklerde pozitif yönde zayıf korelasyon görüldü.

Sonuç: Parkinson hastalarında fiziksel aktivite seviyesi arttıkça depresif belirtiler düzeyinin azaldığı bulundu. Yaş arttıkça, fiziksel aktivitenin azaldığı ve depresif belirtiler düzeyinde artış olduğu gözlendi. Ayrıca vücut kütle indeksi yüksek olanlarda depresif belirtiler düzeyinin de arttırdı̆̆ı görüldü. Vücut kütle indeksi ve fiziksel aktivite düzeyi değişikliğinin depresif belirtiler yönelik tedavilerle beraber uygulanmasının olumlu sonuç getireceği görüşündeyiz.

Anahtar kelimeler: Depresyon; Egzersiz; Parkinson Hastalığı

DOI: 10.5798/dicletip.1037838

Yazışma Adresi / Correspondence: Engin Ramazanoğlu, Inönü Üniversitesi, Sağlık Bilimleri Enstitüsü, Fizyoterapi ve Rehabilitasyon Bölümü, 44000, Battalgazi/Malatya, Türkiye e-mail: enginramazanoglu@hotmail.com 


\section{Investigation of The Relationship Between Depression Symptoms and Physical Activity Level In Parkinson's Disease}

\section{Abstract}

Objective: The aim of this study was to examine the relationship between depressive symptoms and physical activity level in Parkinson's disease.

Methods: A total of 69 patients, including 25 females (36.2\%) and 44 males (63.8\%), aged between 58-89 years were included in this prospective study. The Hamilton Depression Rating Scale was used to determine the severity of depressive symptoms, and the International Physical Activity Questionnaire (Short form) was used to determine the physical activity level in patients with Parkinson's disease.

Results: While a moderate negative significant correlation was observed between the International Physical Activity Questionnaire and Hamilton Depression Rating Scale in all patients and males, there was no statistically significant correlation in females. A moderate negative significant correlation was observed between age and the International Physical Activity Questionnaire in all patients, females and males. While a moderate positive significant correlation was found between the hamilton depression rating scale and age in all patients and females, a highly positive significant correlation was found in males. Whereas a moderate positive significant correlation was observed between body mass index and the hamilton depression rating scale in all patients and females, a weak positive correlation was observed in males.

Conclusion: It was found that the level of depression decreased as the level of physical activity increased in patients with Parkinson's disease. It was observed that physical activity decreased and the level of depressive symptoms increased as the age increased. Furthermore, it was observed that the level of depressive symptoms increased among those with a high body mass index. we think that the application of changes in body mass index and physical activity level together with the treatments for depressive symptoms will provide positive outcomes.

Keywords: Depression, exercise, Parkinson's disease

\section{GÍRIŞ}

Parkinson hastalığı $(\mathrm{PH})$, genetik ve çevresel faktörlerin ortaklaşa neden olduğu beyinde substantia nigrada dopaminerjik nöron harabiyetine bağlı olarak gelişen motor ve motor olmayan bulguların bir arada bulunabildiği, ilerleyici, nörodejeneratif bir hastalıktır ${ }^{1}$. Literatürde, Parkinson hastalığının dünya genelinde görülme prevalansı 18328/100000 olduğu bildirilirken², ülkemizde bu oranın 111/100000 olduğu belirtilmiștir3.

Parkinson hastalığının ana motor semptomları olarak; tremor, bradikinezi, akinezi, rijidite ve postural instabilite görülürken, ayağını sürüyerek yürüme, festinasyon, donma, günlük yaşam aktivitelerinin yavaşlaması, spazm ve distoni gibi sekonder semptomlar da görülebilmektedir ${ }^{4}$. Motor olmayan semptomlara bakıldığında depresyon; hastaların yaklaşık \%30-50 sinde görülen ve en şiddetli semptom olarak karşımıza çıkmaktadır. Hastalığın ilerlemesi ile birlikte görülme sıklığı artış göstermektedir ${ }^{5,6}$. Olguların çoğunda; depresyon şiddeti hafif-orta düzeydedir ve majör depresyon veya distimi şeklinde de görülebilmektedir7. Parkinson hastalığında motor ve motor olmayan semptomlarla beraber; postür, denge, yürüme ve transfer gibi fonksiyonel aktivitelerde azalmalar gözlemlenmektedir. Bazı çalışmalarda, Parkinson hastalığının motor belirtileri ile depresyon arasında anlamlı bir ilişki gösterilememiş ise de $\mathrm{e}^{9,10}$ hastalığın aktiviteleri gerçekleştirme becerisinde azalma gibi fiziksel yönlerinin; stres, anksiyete, iletişim zorlukları gibi diğer belirleyicilerle birlikte hastaların günlük aktivite düzeyini azaltabileceğini ve izolasyonlarını arttırarak hastalarda depresyonu tetikleyebileceğini ifade eden çalışmalar da mevcuttur ${ }^{11}$. Choen ve arkadaşları 
Parkinson hastalığında yaptığı çalışmada egzersizin, fiziksel zindeliği iyileștirdiği ancak depresyon üzerinde herhangi bir etkisinin olmadığını bildirmişlerdir ${ }^{12}$. Parkinson hastalığında depresyonun, motor semptomlara karşı psikolojik bir reaksiyon mu yoksa Parkinson hastalığının patofizyolojisine ikincil bir cevap $\mathrm{ml}$ olduğu yanit bekleyen sorulardandır7,13. Parkinson hastalığının semptomları bireylerin özellikle günlük yaşam aktivitelerine katılım düzeylerini doğrudan etkileyebilmektedir. $\mathrm{Bu}$ etkiler literatürde sıklıkla ele alınmış olup hastalardaki motivasyonel kayıp günlük yaşam aktivitelerine katılmak isteklerindeki azalmanın Parkinson hastalarını hareketsiz bir yaşama sürükleyen kısır bir döngü içerisinde olduğu düşünülmüştür ${ }^{14}$. Çalışmamızın literatüre yapmak istediği katkı parkinson hastalığına sekonder olarak geliştiği düşünülen fiziksel aktivite ve depresif belirtiler arasındaki ilişkinin kanıtlanması ve tedavi programlarında birincil olarak ele alınması sonucu daha etkin tedavi programları oluşturulmasına katkı sağlamaktır.

\section{YÖNTEMLER}

\section{Bireyler}

Çalışmaya 58-89 yaş arasında değișen; daha önce uzman bir hekim tarafindan Parkinson hastalığı tanısı almış ve özel bir hastanenin fizik tedavi ve rehabilitasyon ünitesine başvurmuş olan ve parkinson hastalığı dişında nörolojik (inme, multiple skleroz, alzheimer, epilepsi, beyin damar hastalıkları, periferik sinir hastalıkları, beyin ve omurilik tümörleri vb.) ve ortopedik hastalığı (kırık, kalça, diz ve ayak bileği eklemlerinde eklem hareket açıklığını kısıtlayan problemler) olmayan, değerlendirme ölçeklerini algılayabilecek düzeyde olan (iletişim kurmaya açık, soruları anlayarak mantıklı cevaplar verebilen), depresif belirtilere yönelik ilaç kullanmayan, demans tanısı olmayan (bir fizyoterapist tarafindan hastalarla sözel sorgulama yoluyla) kendilerinden aydınlatılmış onam formu alınmış, gönüllü olarak çalışmaya katılmak isteyen hastalar çalışmaya dahil edildi. Parkinson hastalı̆̆ı dışında belirgin nörolojik ve ortopedik hastalı̆̆ kapall, değerlendirme ve tedavi sürecine uyum sağlayamayacak düzeyde olan, çalışmaya katılmayı reddeden hastalar çalışma dışı kaldı. Başlangıçta 82 birey ile başlanmış olup, çalışma izni boyunca hastaneye müracaat eden, dahil edilme kriterlerini karşılayan, çalışmaya gönüllü olarak katılmayı kabul eden ve kendilerinden aydınlatılmış onam formu alınan 69 kişi ile çalışma tamamlandı. 82 hastadan 2'si eşlik eden, tanılanmış nörolojik hastalığı olduğu, 3'ü fiziksel aktivite düzeylerini etkileyecek ortopedik problemlerin varlı̆g (talus kırığı, total diz protezi sonrası yerleşmiş diz fleksiyon limitasyonu, menisküs yaralanması), 2'si depresyif belirtilere yönelik ilaç kullandığğ, 4'ü ileri yaş nedeniyle iletişim kurmaya kapalı oldukları, 2'si çalışmaya katılmayı reddettikleri gerekçesiyle toplam 13 hasta çalışmadan dışlandı. Dahil edilme ve dışlanma kriterlerin sorgulanması bir fizyoterapist tarafından sözel olarak gerçekleştirilmiştir. Araştırmaya katılmayı kabul eden ve dahil edilme kriterlerini sağlayan hastalar ilgili evrenden olasılıksız rastlantısal örnekleme yöntemi ile seçildi. Bir üniversitenin girişimsel olmayan araştırmalar etik kurulu tarafından etik kurul onayı alındı (27.02.2018 tarihinde, 2018/54 sayıli). Hastalardan aydınlatılmış onam alındı ve çalışma Helsinki Bildirgesinde yer alan kriterlere uygun olarak gerçekleştirildi. Çalışmamız kurum izni ve etik kurul iznini takiben, bir özel hastanenin nöroloji polikliliğine başvurmuş Parkinson tanılı hastalar üzerinde Mart 2018- Eylül 2018 tarihleri arasında tarihleri arasında 6 ay süreyle yürütüldü.

\section{Yöntem}

Çalışmada kullanılan ölçekleri ve demografik verilerin sorgulanması bir fiztyoterapist 
tarafından sözel olarak gerçekleştirilmiş olup, her bir hastanın sorgulanması 30 dakika sürdü. Hastaların Demografik Değerlendirmesi

Demografik veri formu hastaları tanımlayan ve demografik özellikleri araştıran sorulardan oluşmaktaydı.

\section{Hamilton Depresyon Değerlendirme Ölçeği (HDDÖ)}

Hamilton depresyon değerlendirme ölçeği (HDDÖ), Parkinson hastalığında depresif belirtilerin şiddetini belirlemek için kullanıldı. Hamilton tarafından geliştirilen ölçek ${ }^{15}$, dünyada en yaygın kullanılan gözlemci derecelendirmeli depresyon ölçeğidir ${ }^{16}$. Depresyon araștırmalarında altın standart olarak kabul edilir ${ }^{17}$. Ölçekte; uyku, somatik semptomlar, genital semptomlar, kilo kaybı ve iç görü ile ilgili maddeleri 0-2 arasında, diğer maddeler 0-4 arasında puanlanmaktadır. Ölçekte en yüksek 53 puan alınır ${ }^{18}$. 0-7 puan depresyon olmadığını, 8-16 puan arası hafif depresyonu, 17-23 arası orta derece depresyonu, 24 ve üzeri şiddetli depresyonu belirtmektedir ${ }^{19}$. Ölçeğin, Türkçe geçerlilik ve güvenirlilik çalışması bulunmaktadır ${ }^{20}$. Hamilton Depresyon Değerlendirme Ölçeği iç tutarlılık çalışmasında Cronbach alfa değeri 0.75 , güvenirlik katsayısı 0.76 olarak bulunmuştur21.

\section{Uluslararası Fiziksel Aktivite Ölçeği (Kısa Form) (UFAA)}

Uluslararası fiziksel aktivite ölçeği (kısa form); Parkinson hastalığında fiziksel aktivite seviyesini belirlemek için kullanıldı. Ölçeğin Türkçe geçerlilik ve güvenirlilik çalışması bulunmaktadır ${ }^{22}$. Uluslararası Fiziksel Aktivite Anketi kısa formda test tekrar test güvenirlik katsayısı 0,69 bulunmuştur ${ }^{22}$.

Hastalardan son 1 hafta içinde fiziksel olarak harcanan zaman hakkında 7 sorudan oluşan anketi cevaplamaları istendi. Fiziksel aktivitelerin, tek seferde en az 10 dakika yapılıyor olması ölçüt alındı. Şiddetli ve orta fiziksel aktivite süreleri, yürüme ve oturma süreleri kaydedildi. Oturma süresi sedanter davranış olarak ayrı ayrı hesaplandı. Dakika, gün ve Metabolik Eşdeğer (MET) değerleri çarpılarak "MET-dakika / gün" skoru elde edildi. 3,3 MET ile yürüme süresi çarpımı, 4 MET' in orta şiddetli fiziksel aktivite ile çarpımı, 8 MET ile şiddetli fiziksel aktivite çarpımı ile toplam fiziksel aktivite skoru elde edildi. Toplam skor 600 MET-dk/hafta nın altı ise düşük düzey, 600-3000 MET-dk/hafta arası orta düzey, 3000 MET-dk/hafta üstü ise yüksek düzey fiziksek aktivite olarak belirlendi ${ }^{23,24}$.

\section{İstatiksel Analiz}

Örneklem büyüklüğü için yapılan power analizinde PASS 13 programı kullanıldı. $\alpha=0,05$ ve $1-\beta$ (güç) $=0,80$ ile Parkinson hastalığında depresyona maruz kalma oranının \%32 olduğu varsayıldığında, çalışmaya; 69 hastanın alınması gerektiği hesapland ${ }^{25}$. İstatistiksel analizler; Sürekli değişkenlerin dağılımının normalliği Shaphiro wilk testi kullanıldı. Sayısal değişkenler arasındaki ilişkiyi değerlendirmek için Spearman rank korelasyon analizi ile değerlendirildi. İki grubun karşılaştırılmasında Student $t$ testi (normal veriler için) ve Mann-Whitney U testi (normal olmayan veriler için) kullanıldı. İstatistiksel analiz SPSS for Windows 24.0 sürümü ile yapıldı ve $\mathrm{p}$ değeri $<0,05$ istatistiksel olarak anlamlı kabul edildi.

Spearman Rank korelasyon katsayıları; çok zayıf korelasyon veya korelasyon yok:0,00-0,10; zayıf korelasyon:0,10-0,39; orta şiddette korelasyon:0,40-0,69; yüksek korelasyon:0,700,89; çok güçlü korelasyon:0,90-1,00 olarak ifade edildi ${ }^{26}$.

\section{BULGULAR}

$\mathrm{Bu}$ prospektif çalışmaya; yaşları 58-89 arasında değişen 44 erkek $(72,09 \pm 7,67$ yll $)$ ve 25 kadın $(72,24 \pm 7,6$ yll $)$ olmak üzere toplam $69(72,14 \pm$ $7,59)$ hasta dahil edildi. Çalışmaya katılan hastaların; yaş ortalaması; 72,14 $\pm 7,59$ yıl, boy; $1,68 \pm 0,09 \mathrm{~m}$, vücut ağırlı̆̆ı; $79,07 \pm 8,94 \mathrm{~kg}$ ve vücut kütle indeksi (VKI); 27,95 $\pm 2,97 \mathrm{~kg} / \mathrm{m} 2$ olarak bulundu (Tablo 1). 
Tablo I: Katılımcıların Demografik Karakteristikleri

\begin{tabular}{|c|c|c|}
\hline Variables & Mean \pm SD & Median (Min-Max) \\
\hline Age (year) & $72,14 \pm 7,59$ & $71(58-89)$ \\
\hline Height (m) & $1,68 \pm 0,09$ & $1.7(1.5-1.85)$ \\
\hline Body weight & $79,07 \pm 8,94$ & $80(55-101)$ \\
\hline BMI $\left(\mathrm{kg} / \mathrm{m}^{2}\right)$ & $27,95 \pm 2,97$ & $27,38(21.22-36.21)$ \\
\hline UFAA (met) & $690,43 \pm 431,26$ & $662(0-2976)$ \\
\hline HDDÖ & $26,67 \pm 8,33$ & $26(10-43)$ \\
\hline
\end{tabular}

BMI: body mass index; m: meter; $\mathrm{kg}$ : kilogram; $\mathrm{kg} / \mathrm{m} 2$ :kilogram/meter2 met: metabolik eșdeğer UFAA: uluslararası fiziksel aktivite anketi; HDDÖ: Hamilton depresyon değerlendirme ölçeği
Çalışmaya katılan hastalar orta düzeyde fiziksel aktivite yapan ve şiddetli depresif belirtileri olan hastalardan oluşmaktaydı. (sırasılya; $690,43 \pm 431,26,26,67 \pm 8,33$ ) (Tablo 1). Çalışmaya katılan erkekler kadınlara göre daha uzun boy ve kiloya sahipti $(\mathrm{p}<0,05)$. Kadınlarda VKİ erkeklere göre daha fazlaydı $(p<0,05)$. Diğer parametreler arasında istatiksel olarak anlamlı farklılık bulunmadı ( $\mathrm{p}>0,05)$ (Tablo 2).

Tablo II: Kadın ve Erkeklerde Karakteristik Özelliklerin Karşılaştırılması

\begin{tabular}{|c|c|c|c|c|}
\hline Değişkenler & Kadın ( $n=25$ ) & Erkek $(n=44)$ & Test ist & $\mathbf{P}$ \\
\hline Age (year) & $72,24 \pm 7,6$ & $72,09 \pm 7,67$ & $\mathrm{t}=0,078$ & 0,938 \\
\hline Height (m) & $1,61 \pm 0,06$ & $1,73 \pm 0,05$ & $t=-9,907$ & 0,001* \\
\hline Body weight & $74,64 \pm 9,18$ & $81,59 \pm 7,84$ & $t=-3,326$ & $0,001 *$ \\
\hline BMI $\left(\mathrm{kg} / \mathrm{m}^{2}\right)$ & $29,32 \pm 3,55$ & $27,17 \pm 2,28$ & $t=3,059$ & $0,003^{*}$ \\
\hline UFAA (met) & $638,34 \pm 336,52$ & $720,02 \pm 477,96$ & $Z=-0,162$ & 0,871 \\
\hline HDDÖ & $28,6 \pm 7,65$ & $25,57 \pm 8,59$ & $\mathrm{t}=1,465$ & 0,148 \\
\hline
\end{tabular}

*Significant at 0,05 level,t:Student t test, Z: Mann whitney u test. BMI: body mass index; m: meter; $\mathrm{kg}:$ kilogram; $\mathrm{kg} / \mathrm{m} 2$ :kilogram/meter2 met: metabolik eșdeğer UFAA: uluslararası fiziksel aktivite anketi; HDDÖ: Hamilton depresyon değerlendirme ölçeği

\section{UFAA ve HDÖÖ skorları arasındaki ilişki}

\section{Tüm hastalar}

UFAA ve HDDÖ arasında negatif yönde orta şiddette anlamlı korelasyon bulundu $(r=-0,475-$ $\mathrm{p}=0,001)$. UFAA ile yaş arasında negatif yönde orta şiddette anlaml korelasyon bulunurken (sirasiyla $r=-0,635-p=0,001$ ), HDDÖ ile yaş Tablo III: Ölçümlerin tüm hastalarda, erkeklerde ve kadınlarda Fiziksel Aktivite ve Depresyon Skorlarının karşılaştırılması

\begin{tabular}{|c|c|c|c|c|c|c|c|}
\hline & \multicolumn{2}{|c|}{ Tüm Hastalar $(\mathrm{n}=69)$} & \multicolumn{2}{|c|}{ Kadın $(n=25)$} & \multicolumn{2}{|c|}{ Erkek $(n=44)$} \\
\hline & & UFA (met) & HDDÖ & UFA (met) & HDDÖ & UFA (met) & HDDÖ \\
\hline \multirow{2}{*}{ HDDÖ } & $\mathrm{r}$ & $-0,475^{*}$ & 1,000 & $-0,367$ & 1,000 & $-0,537^{*}$ & 1,000 \\
\hline & $\mathrm{p}$ & 0,001 & & 0,071 & & 0,001 & \\
\hline \multirow{2}{*}{ Age (year) } & $\mathrm{r}$ & $-0,635^{*}$ & $0,670^{*}$ & $-0,672^{*}$ & $0,607^{*}$ & $-0,604^{*}$ & 0,701* \\
\hline & $\mathrm{p}$ & 0,001 & 0,001 & 0,001 & 0,001 & 0,001 & 0,001 \\
\hline \multirow{2}{*}{ Height (m) } & $\mathrm{r}$ & 0,169 & $-0,271^{*}$ & $0,598^{*}$ & $-0,273$ & 0,054 & $-0,116$ \\
\hline & $\mathrm{p}$ & 0,165 & 0,024 & 0,002 & 0,187 & 0,726 & 0,452 \\
\hline \multirow{2}{*}{ Body weight } & $\mathrm{r}$ & $-0,156$ & 0,224 & $-0,012$ & 0,189 & $-0,275$ & $0,351^{*}$ \\
\hline & $\mathrm{p}$ & 0,202 & 0,064 & 0,955 & 0,365 & 0,071 & 0,020 \\
\hline \multirow{2}{*}{ BMI $\left(\mathrm{kg} / \mathrm{m}^{2}\right)$} & $\mathrm{r}$ & $-0,277^{*}$ &, $426^{*}$ & $-0,343$ & $0,443^{*}$ & $-0,274$ & $0,385^{*}$ \\
\hline & $\mathrm{p}$ & 0,021 & 0,001 & 0,094 & 0,027 & 0,072 & 0,010 \\
\hline
\end{tabular}

arasında pozitif yönde orta şiddette anlamlı korelasyon bulundu $(\mathrm{r}=0,670-\mathrm{p}=0,001)$. Boy ile HDDÖ arasında negatif yönde zaylf şiddette anlamlı korelasyon bulundu ( $\mathrm{r}=-0,271-\mathrm{p}=0,024)$. VKİ ile HDDÖ arasında pozitif yönde orta şiddette anlamlı korelasyon saptandl $(\mathrm{r}=, 426-\mathrm{p}=0,001)$ (Tablo 3). 


\section{Cinsiyete Göre İlişki}

\section{Kadınlar}

UFAA ile HDDÖ arasında düşük düzeyde ilișki görülse de, istatistiksel olarak anlamlı değildi ( $r=-0,367, p=0,071)$. UFAA ile yaş arasında negatif yönde orta şiddette anlamlı korelasyon ( $\mathrm{r}=-0,672-\mathrm{p}=0,001)$, HDDÖ ile yaş arasında pozitif yönde orta şiddette anlamlı korelasyon bulundu ( $r=0,607-p=0,001)$. UFAA ile boy arasında pozitif yönde orta şiddette anlamlı korelasyon bulundu $(\mathrm{r}=0,598-\mathrm{p}=0,002)$. VKİ ile HDDÖ arasında pozitif yönde orta şiddette anlamlı korelasyon saptand $\mathrm{l} \quad(\mathrm{r}=0,443-\mathrm{p}$ $=0,027$ ) (Tablo 3).

\section{Erkekler}

UFAA ve HDDÖ arasında negatif yönde orta şiddette anlamlı korelasyon bulundu $(r=-0,537$ $\mathrm{p}=0,001$ ). UFAA ile yaş arasında negatif yönde orta şiddette anlaml korelasyon ( $\mathrm{r}=-0,604$ $\mathrm{p}=0,001$ ), HDDÖ ile yaş arasında pozitif yönde yüksek şiddette anlamlı korelasyon saptandı ( $r=0,701-p=0,001)$. Vücut ağırlığı ve VKİ ile HDDÖ arasında pozitif yönde zayıf korelasyon saptandı (sırasiyla $r=0,351-p=0,020 r=0,385$ $\mathrm{p}=0,010)$.

\section{TARTIŞMA}

$\mathrm{Bu}$ çalışma; Parkinson hastalığında depresif belirtiler ile fiziksel aktivite seviyesi arasındaki ilişkinin incelenmesi ve fiziksel aktivitenin depresif belirtiler ile seyreden Parkinson hastalığı üzerine etkilerinin belirlenmesi amacıyla yapıldı. Çalışmaya; 58-89 yaşları arası, 25 kadın ve 44 erkek olmak üzere toplam 69 hasta dahil edildi. Parkinsonlu hastalarda artan yaş ile beraber, fiziksel aktivite seviyelerinin azaldığı ve depresif belirtiler düzeylerinde artış olduğu gözlendi. Ayrıca VKİ yüksek olan hastalarda depresif belirtiler düzeyinin de arttığı görüldü. Parkinson hastalığında, fiziksel aktivitenin fiziksel fonksiyonları geliştirmek ve depresif belirtileri azaltmak için etkili bir yöntem olduğunu belirtilmektedir ${ }^{27}$. Fiziksel aktivitenin; ß- endorfin salınımı arttırması, serotonin, dopamin ve noradrenalin gibi nörotransmitterlerin veya beyinden türetilmiş nörotrofik faktörlerin mevcudiyetinde artış sağlayarak depresif belirtiler üzerinde olumlu etkiler sağladığı bildirilmiștir ${ }^{28}$. Literatürde; fiziksel aktivite ve depresif belirtiler arasında negatif yönde bir ilişki olduğu ve fiziksel aktivite arttıkça depresif belirtiler azaldığı bildirilmiştir29,31. Ayrıca fiziksel aktivite yapmayan bireylerin depresif semptomlarında artış olduğu gözlenmiștir ${ }^{32}$. Literatürde yer alan bu bilgilerin ışığında çalışmamız da UFAA ile HDDÖ arasında tüm bireylerde ve erkeklerde negatif yönde orta şiddetli korelasyon bulgularını desteklemektedir. $\mathrm{Bu}$ ilişkinin fiziksel aktiviteyle beraber beyin kaynakl nörotransmitter ve nörotrofik faktörlerin artışıyla ilgili olabileceğini düşündürmektedir. Kadınlarda istatiksel olarak anlamlı bir ilişki bulunmamasının örneklem küçüklüğünden kaynaklandığını düşünmekle beraber, bu konuda ileri çalışmalar yapılabileceği görüşündeyiz.

Parkinson hastalığında yaş, bir risk faktörü olarak kabul edilmektedir. İlerleyen yaşın, Parkinson hastalığında motor fonksiyonlarda daha hızlı kayıp, levodopaya azalmış tepki, daha şiddetli yürüyüş ve postüral bozukluk ve daha şiddetli kognitif bozukluk ve demans gelişimi ile ilişkili olduğu belirtilmiştir ${ }^{33}$. Parkinson hastalığında yaş arttıkça; yönetici işlev bozukluğu, hafiza ve görsel uzamsal bozukluklar gibi kognitif bozukluklar da meydana gelmektedir. $\mathrm{Bu}$ bozukluklarla beraber yürütme işlevleri, hedefe yönelik davranışı planlama, organize etme ve düzenleme becerisi gibi yaşamsal bazı becerilerde olumsuz yönde etkilenir ${ }^{34}$. Bu konuda bulgularımı literatürle paralellik gösterdi. Yaş ile UFAA arasında negatif yönde korelasyonun olması ilerleyen yaşla birlikte meydana gelen kognitif ve motor fonksiyon kayıplarıyla ilgili olduğunu düşündürmektedir. 
Literatürde Parkinson hastalığında depresyonun; yaş, hastalığın başlangıç yaşı ve antiparkinson ilaç kullanımıyla ilişkili olduğu belirtilmiştir ${ }^{35,36}$. Starkstein ve arkadaşları Parkinson hastalığında, erken ve geç başlangıçlı grupların karşılaştırdığı çalışmalarında, hastalığın erken başlangıçlı grubunda önemli ölçüde daha yüksek depresyon skorlarına sahip olduğunu bildirmişlerdir ${ }^{37}$. Ayrıca yaşlanmayla beraber striatumda dopamin D2 reseptörlerin kaybı gözlenmektedir ${ }^{38}$. Bulgularımızda; HDDÖ ile yaş arasında pozitif yönde korelasyon gözlenmesi literatürle uyumluydu. Beyer ve ark., Parkinson hastalığı bulunan bireylerin daha düşük vücut kütle indeksi ve vücut ağırlığına sahip olduğunu belirtmiștir ${ }^{39}$. Parkinson hastalığının genel olarak mı yoksa sadece hastalığa sahip bir alt grubunun mu, hastalığın ileri evrelerinde daha düşük VKİ gösterip göstermediği net değildir ${ }^{40}$. Çalışmamıza katılan bireylerde VKİ'nin Dünya Sağlık Örgütü sınıflamasına göre preobez bireyler olduğu gözlenmektedir. VKİ artışıyla beraber inflamatuar yolların aktifleștiği ve depresyon üzerinde etkili olduğu bildirilmiştir ${ }^{41}$. Aynı zamanda VKİ artışıyla beraber hipotalamus hipofiz adrenal aks'ın hiperaktivitesinin depresyon üzerinde etkili olduğu bilinmektedir ${ }^{42}$. Ayrıca literatürde VKI artışına bağlı olarak psikolojik stresin de depresyonu tetiklediği bildirilmiştir ${ }^{43}$. Bulgularımızda tüm bireylerde ve kadınlarda VKİ ile HDDÖ arasında pozitif yönde orta şiddette, erkeklerde pozitif yönde zayıf şiddette korelasyon ve erkeklerde vücut ağırlığı ile HDDÖ arasında pozitif yönde zayıf korelasyon bulgusunun literatürdeki bilgilerin ışığında; Parkinson hastalığına eşlik eden biyolojik ve psikolojik etkilerden kaynaklandığı düşünmekteyiz.

\section{Limitasyonlar}

Çalışmamızın bazı limitasyonları bulunmaktadır; örneklemimizde kadın sayısının az olması, hastaların leva dopa kullanım sürelerinin sorgulanmamış olması ve hastalığın başlangıç süresi ile ilgili net bilginin bulunmaması ve kontrol grubu olmaması çalışmamızın limitasyonlarındandır

\section{SONUÇ}

Yaş arttıkça, fiziksel aktivitenin azaldığı ve depresif belirtilerin artış olduğu gözlendi. Ayrıca VKİ yüksek bireylerde depresyon düzeyinin de yüksek olduğu gözlendi. Parkinsonlu bireylerin depresyonuna yönelik tedavilerde; bireylerin yaşları, depresyon düzeyleri ve fiziksel aktivite seviyeleri arasındaki ilişkinin göz önünde bulundurularak, VKI ve fiziksel aktivite değişikliği içeren egzersiz reçetelerinin uygulanmasının hasta için daha olumlu sonuçlar doğuracağını düşünmekteyiz.

Etik Kurul Kararı: İnönü Üniversitesi Girişimsel Olmayan Araştırmalar Etik Kurulu tarafindan etik kurul onayı alındı (27.02.2018 tarihinde, 2018/54 sayılı).

Çıkar Çatışması Beyanı: Yazarlar çıkar çatışması olmadığını bildirmişlerdir.

Finansal Destek: Bu çalışma herhangi bir fon tarafından desteklenmemiştir.

Declaration of Conflicting Interests: The authors declare that they have no conflict of interest.

Financial Disclosure: No financial support was received.

\section{KAYNAKLAR}

1. Hsiu-Chen C, Chiung-Chu C, Jiunn-Woei L, et al. The effects of dual-task in patients with Parkinson's disease performing cognitive-motor paradigms. J Clin Neurosci. 2020; 72: 72-8.

2. AH Rajput, S Birdi. "Epidemiology of Parkinson's disease," Parkinsonism Relat Disord. 1997; 175-86.

3. R. Çakmur, "Parkinson Hastalığının Epidemiyoloisi ve Klinik Özellikleri," Ankara: Turkiye Klinikleri J Neur, 2003; 160-3. 
4. Balestrino R, Schapira AHV. Parkinson disease. European journal of neurology, Eur J Neurol 2020; 27: 27-42.

5. Ossowska K, Lorenc-Koci E. Depression in Parkinson's disease. Pharmacological Reports. 2013; 65: 1545-57.

6. Rickards H. Depression in neurological disorders: Parkinson's disease, multiple sclerosis, and stroke. J Neurol Neurosurg Psychiatry. 2005; 76 (suppl 1): i48-i52.

7. Mayeux R, Stern Y, Williams JB, et al. Clinical and biochemical features of depression in Parkinson's disease. Am J Psychiatry 1986; 143: 756-9.

8. Bhalsing KS, Abbas MM, Tan LC. Role of physical activity in Parkinson's disease. Ann Indian Acad Neurol 2018; 21: 242-9.

9. Mayeux R, Stern Y, Cote L, et al. Altered serotonin metabolism in depressed patients with Parkinson's disease. Neurology 1984 May; 34: 642-6.

10. Santamaria J, Tolosa E, Valles A. Parkinson's disease with depression: a possible subgroup of idiopathic parkinsonism. Neurology 1986; 36: 11303.

11. Hartley S, McArthur $M$, Coenen $M$, et al. Narratives reflecting the lived experiences of people with brain disorders: common psychosocial difficulties and determinants. PLoS One 2014; 7; 9: e96890.

12. Cheon SM, Chae BK, Sung HR, et al. The efficacy of exercise programs for Parkinson's disease: Tai Chi versus combined exercise. J Clin Neurol 2013 Oct; 9: 237-43.

13. Shulman LM, Taback RL, Bean J, et al. Comorbidity of the nonmotor symptoms of Parkinson's disease. Mov Disord 2001 May; 16: 50710.

14. Saygllı BN. Parkinson hastalarında fiziksel aktivite düzeyi ile bilişsel durum arasındaki ilişki (Master's thesis, İstanbul Medipol Üniversitesi Sağlık Bilimleri Enstitüsü), 2019.

15. Gibbons RD, Clark DC, Kupfer DJ. Exactly what does the Hamilton depression rating scale measure? J Psychiatr Res Jul-Sep 1993; 27: 259-73.
16. Bagby RM, Ryder AG, Schuller DR, et al. The Hamilton Depression Rating Scale: has the gold standard become a lead weight?. Am J Psychiatry 2004 Dec; 161: 2163-77.

17. Stefanis CN, Stefanis NC. Diagnosis of depressive disorders: A review. Depressive disorders, 2002; 187.

18. Williams JBA. structured interview guide for the Hamilton Depression Rating Scale. Arch Gen Psychiatry 1988 Aug; 45: 742-7.

19. Zimmerman M, Martinez JH, Young D, et al. Severity classification on the Hamilton depression rating scale. J Affect Disord 2013; 5; 150: 384-8.

20. Akdemir A, Örsel S, Dağ İ, et al. Hamilton Depresyon Derecelendirme Ölçeği (HDDÖ)'nin geçerliği, güvenirliği ve klinikte kullanımı. Psikiyatri Psikoloji Psikofarmakoloji Dergisi, 1996; 4: 251-9.

21. San A, Erensoy H, Aytaç HM, et al. Üniversite öğrencilerinde depresyon düzeylerinin, madde kullanımları ve aile tutumları ile ilişkisi. Bağımlılık Dergisi. 2020; 21; 1-12.

22. Saglam M, Arikan H, Savci S, et al. International physical activity questionnaire: reliability and validity of the Turkish version. Percept Mot Skills 2010; 111: 278-84.

23. Angın E, Topcu ZG, Yatar İ, et al. Assessment of physical activity and academic success levels in physiotherapy and rehabilitation students. JETR, 2018; 5: 33-7.

24. Abdurrahman G, Şener Ü, Karabacak H, ve ark. Kadın ve erkek genç erişkinler arasında fiziksel aktivite ve yaşam kalitesi farklılıklarının araştırılması. Kocatepe Tıp Dergisi, 2011; 12: 14550.

25. Kelsey JL, Whittemore AS, Evans AS, et al. Methods in observational epidemiology. Monographs in Epidemiology. 2nd edition. Vol. 10. 1996.

26. Schober P, Boer C, Schwarte LA. Correlation coefficients: appropriate use and interpretation. Anesth Analg. 2018; 126: 1763-8.

27. Van der Kolk NM, King LA. Effects of exercise on mobility in people with Parkinson's disease. Mov Disord. 2013; 15; 28: 1587-96. 
28. Dietrich A, McDaniel WF. Endocannabinoids and exercise. Br J Sports Med. 2004; 38: 536-41.

29. Huang TT, Liu CB, Tsai YH, et al. Physical fitness exercise versus cognitive behavior therapy on reducing the depressive symptoms among community-dwelling elderly adults: A randomized controlled trial. Int J Nurs Stud. 2015; 52: 1542-52.

30. Park SH, Han KS, Kang CB. Effects of exercise programs on depressive symptoms, quality of life, and self-esteem in older people: a systematic review of randomized controlled trials. Appl Nurs Res. 2014; 27: 219-26.

31. Wu PL, Lee M, Huang TT. Effectiveness of physical activity on patients with depression and Parkinson's disease: A systematic review. PLoS One 2017; 27; 12: e0181515.

32. Dankel SJ, Loenneke JP, Loprinzi PD. Mild depressive symptoms among Americans in relation to physical activity, current overweight/obesity, and self-reported history of overweight/obesity. Int J Behav Med. 2016; 23: 553-60.

33. Levy G. The relationship of Parkinson disease with aging. Arch Neurol 2007; 64: 1242-6.

34. Kaasinen V, Rinne JO. Functional imaging studies of dopamine system and cognition in normal aging and Parkinson's disease. Neurosci Biobehav Rev 2002; 26: 785-93.

35. Brown RG, MacCarthy B, Gotham AM, et al. Depression and disability in Parkinson's disease: a follow-up of 132 cases. Psychol Med 1988; 18: 4955.
36. Remy P, Doder M, Lees A, et al. Depression in Parkinson's disease: loss of dopamine and noradrenaline innervation in the limbic system. Brain 2005; 128: 1314-22.

37. Starkstein SE, Berthier ML, Bolduc PL et al. Depression in patients with early versus late onset of Parkinson's disease. Neurology 1989; 39: 1441-5.

38. Kaasinen V, Vilkman H, Hietala J et al. Age-related dopamine D2/D3 receptor loss in extrastriatal regions of the human brain. Neurobiol Aging. 2000; 21: 683-8.

39. Beyer PL, Palarino MY, Michalek D et al.. Weight change and body composition in patients with Parkinson's disease. J Am Diet Assoc 1995; 95: 97983.

40. Bachmann CG, Trenkwalder C. Body weight in patients with Parkinson's disease.

Mov Disord 2006; 21: 1824-30.

41. Ferrante Jr, AW. Obesity-induced inflammation: a metabolic dialogue in the language of inflammation. J Intern Med, 2007; 262: 408-14.

42. Iob E, Kirschbaum C, Steptoe A. Persistent depressive symptoms, HPA-axis hyperactivity, and inflammation: the role of cognitive-affective and somatic symptoms. Mol Psychiatry 2020; 25: 113040 .

43. Luppino FS, De Wit LM, Bouvy PF et al. Overweight, obesity, and depression: a systematic review and meta-analysis of longitudinal studies. Arch Gen Psychiatry 2010; 67: 220-9. 